\title{
IMPROVEMENT OF POETRY WRITING SKILL THROUGH AUDITORY, INTELLECTUALLY, REPETITION (AIR) BASED ON OUTDOOR STUDY (Classroom Action Research of Third Grade at SD Negeri Soropadan No. 108 Surakarta Academic Year 2017/2018)
}

\author{
Proborini, Retno Winarni, Lies Lestari \\ Universitas Sebelas Maret \\ probo.rini1272@gmail.ac.id
}

\section{Article History}

accepted 09/07/2018

approved 01/08/2018

published 17/09/2018

\section{Keywords}

Poetry writing skill,

Auditory Intellectually

Repetition, Outdoor Study

\begin{abstract}
The aim of this research to improve poetry writing skill through Auditory, Intellectually, Repetition (AIR) based on Outdoor Study for third grade students at SD Negeri Soropadan 108 Surakarta academic year 2017/2018. This research form was Classroom Action Research. It conducted by two cycles. Each cycle consist of planning, acting, observing, and reflecting. Data collection technique used interview, observation, test, and documentation. Data validity technique used content validity, resources triangulation, and technique triangulation. Data analysis technique consisted by data collection, data reduction, data display, and conclusion. The result of this research indicated improvement of poetry writing skill of third grade students at SD Negeri Soropadan 108 Surakarta academic year 2017/2018 from preaction $29,73 \%$, cycle I $54,05 \%$, and cycle I/ 89,19\%. The conclusion of this research indicated that through Auditory, Intellectually, Repetition (AIR) based on Outdoor Study can improve student writing skill of third grade students at SD Negeri Soropadan 108Surakarta academic year 2017/2018.
\end{abstract}

Social, Humanities, and Education Studies (SHEs): Conference Series https://jurnal.uns.ac.id/shes
p-ISSN 2620-9284

e-ISSN 2620-9292 


\section{PENDAHULUAN}

Bahasa merupakan alat untuk menyampaikan pikiran, gagasan, konsep atau perasaan individu kepada orang lain. Terdapat beragam bahasa di dunia ini, di Indonesia sendiri terdapat banyak bahasa daerah dengan satu bahasa nasional yang menjadi bahasa pemersatu, yaitu bahasa Indonesia. Upaya menjaga bahasa pemersatu tersebut dengan menjadikan bahasa Indonesia sebagai mata pelajaran wajib di sekolah mulai dari tingkatan sekolah dasar, menengah, hingga lanjutan. Bahasa Indonesia juga merupakan bahasa resmi yang digunakan sebagai bahasa pengantar dalam dunia pendidikan.

Pembelajaran Bahasa Indonesia merupakan serangkaian aktivitas yang dilakukan siswa untuk mencapai keterampilan berbahasa. Keterampilan berbahasa itu meliputi: keterampilan menyimak, keterampilan berbicara, keterampilan membaca, dan keterampilan menulis. Setiap keterampilan, berhubungan erat dengan tiga keterampilan lainnya. Keterampilan menulis perlu dikembangkan ditingkat Sekolah Dasar. Hal tersebut dikarenakan keberhasilan siswa dalam mengikuti kegiatan belajar mengajar di sekolah banyak ditentukan oleh keterampilannya dalam menulis. Dalman ( 2016) mengatakan bahwa menulis adalah suatu kegiatan komunikasi berupa penyampaian pesan secara tertulis kepada pihak lain dengan menggunakan bahasa tulis sebagai medianya.

Keterampilan menulis merupakan keterampilan berbahasa yang harus mendapatkan perhatian lebih. Hal tersebut didasarkan pada pendapat Nurgiyantoro (2016) yang mengatakan bahwa aktivitas menulis merupakan suatu bentuk manifestasi kompetensi berbahasa paling akhir dikuasai pembelajar bahasa setelah kompetensi menyimak, berbicara dan membaca. Keterampilan menulis yang diajarkan di Sekolah Dasar salah satunya adalah keterampilan menulis puisi. Keterampilan menulis puisi ini diberikan mulai dari kelas rendah dan kemudian berlanjut di kelas tinggi.

Puisi merupakan salah satu ragam sastra yang bahasanya terikat oleh irama, mantra, dan rima dalam susunan larik dan bait (Nadeak dalam Winarni: 2014). Dalam keterampilan menulis puisi di sekolah dasar, siswa diajarkan untuk mengungkapkan gagasan, pikiran, maupun curahan perasaan dengan menggunakan bahasa yang mengandung nilai estetika. Penulisan puisi selain menggunakan bahasa yang indah, juga menggunakan bahasa yang ringkas, namun sangat bermakna. Pengungkapan kata-kata dalam puisi selanjutnya dituangkan dalam bentuk baris-baris atau bait, dan tidak berbentuk paragraf.

Berdasarkan kegiatan observasi dan wawancara yang dilakukan dengan guru kelas III SD Negeri Soropadan No. 108 Surakarta, mengungkap bahwa salah satu permasalahan dalam mata pelajaran Bahasa Indonesia adalah perihal menulis puisi. Siswa belum mampu mengungkapkan sesuatu yang dipikirkan dan dirasakannya dalam bentuk puisi. Hal tersebut disebabkan karena dalam pembelajaran Bahasa Indonesia, guru lebih fokus mengajarkan keterampilan berbahasa yang lainnya dan mengesampingkan keterampilan menulis puisi dengan tidak memberikan pendampingan dalam proses menulis. Padahal sebagaimana telah dipaparkan sebelumnya, keterampilan menulis merupakan keterampilan yang kompleks karena siswa terlebih dahulu harus menguasai tiga keterampilan berbahasa yang lain. Hal tersebut seharusnya dijadikan sebuah pertimbangan oleh guru dalam mengajarkan keterampilan menulis kepada siswa. Wawancara yang dilakukan kepada siswa memberikan pembenaran atas kondisi tersebut. Siswa masih merasa bingung dan kesulitan untuk menulis puisi.

Hasil pretest menunjukkan hanya terdapat 11 siswa atau $29,73 \%$ dari 37 siswa yang mendapatkan nilai $\geq 70$ (batas KKM), sedangkan 26 siswa atau 70,27\% lainnya mendapat nilai di bawah 70 . Hasil penilaian keterampilan menulis puisi dari kegiatan pretest yang telah dilakukan, menunjukkan lebih dari separuh siswa mendapat nilai dibawah KKM.

Berdasarkan hasil kegiatan pratindakan yang telah dilakukan, dapat diidentifikasikan faktor-faktor yang melatarbelakangi rendahnya keterampilan menulis puisi pada siswa kelas III SD Negeri Soropadan No. 108 Surakarta. Faktor-faktor 
tersebut diantaranya adalah (1) model pembelajaran yang digunakan guru dalam pembelajaran adalah model pembelajaran yang masih konvensional; (2) belum adanya variasi media pembelajaran yang merangsang kreativitas siswa; (3) siswa merasa bosan terhadap pembelajaran Bahasa Indonesia yang monoton; (4) guru lebih berorientasi pada hasil sehingga kurang memperhatikan proses pendampingan kepada siswa dalam hal menulis. Faktor-faktor penyebab rendahnya keterampilan menulis puisi tersebut apabila tidak diatasi tentu akan memberikan dampak lanjutan. Hal tersebut tentu akan sangat berpengaruh pada pembelajaran dengan materi serupa, baik di kelas yang lebih tinggi nantinya, maupun dijenjang pendidikan berikutnya.

Solusi yang dapat digunakan dalam meningkatkan keterampilan menulis puisi menurut peneliti adalah dengan menerapkan model pembelajaran kooperatif. Rukayah (2012) mengatakan bahwa pembelajaran kooperatif telah dikembangkan secara intensif melalui berbagai penelitian, tujuannya untuk meningkatkan kerjasama akademik antar siswa, membentuk hubungan positif, mengembangkan rasa percaya diri, serta meningkatkan kemampuan akademik melalui aktivitas kelompok. Model pembelajaran kooperatif memiliki beragam bentuk, adapun yang menurut peneliti akan menjadi solusi dari permasalahan yang telah dipaparkan di atas adalah model pembelajaran kooperatif tipe Auditory, Intellectually, Repetition (AIR). Auditory diartikan dengan pendengaran, Intellectually diartikan dengan pemikiran, dan Repetition diartikan sebagai pengulangan. Gaya belajar auditorial adalah gaya belajar yang mengakses segala jenis bunyi dan kata untuk kemudian diproses dalam ingatan menjadi sesuatu yang bermakna secara internal di dalam pemikiran seorang individu sebagai awal mula proses intelektual dalam dirinya. Adapun pengulangan adalah rangsang yang diberikan sebagai pendalaman, perluasan, dan pemantapan atas materi yang telah diberikan.

Model pembelajaran kooperatif tipe Auditory, Intellectually, Repetition (AIR) akan lebih maksimal apabila dilakukan dengan melibatkan lingkungan belajar yang sesuai (Outdoor Study). Hal tersebut berdasar pada amanat Undang-Undang Sistem Pendidikan Nasional (Sisdiknas) No. 20 Tahun 2003 yang menyatakan bahwa pembelajaran merupakan proses interaksi siswa dengan guru, serta sumber belajar pada suatu lingkungan belajar. Belajar di luar kelas (Outdoor Study) mempunyai manfaat yang tidak didapatkan oleh siswa apabila hanya belajar di dalam kelas. Pembelajaran di luar kelas (Outdoor Study) akan memberikan tambahan motivasi belajar pada siswa, mengasah aktivitas fisik dan kreativitas, adanya media pembelajaran yang konkret, penguasaan keterampilan sosial, mengembangkan sikap mandiri, serta memberikan kesan belajar yang tidak mudah dilupakan oleh siswa.

Peneliti yakin untuk menerapkan model pembelajaran Auditory, Intellectually, Repetition (AIR) berbasis Outdoor Study. Keyakinan tersebut berdasar atas pendapat Slamet (2015: 4) yang mengatakan bahwa menulis adalah sebuah keterampilan yang dapat dipelajari. Berlatih adalah cara untuk mengembangkan keterampilan menulis tersebut. Hal tersebut juga diperkuat dengan pendapat Tarigan (2008: 1) yang mengatakan bahwa keterampilan berbahasa hanya dapat diperoleh dengan dua cara, yaitu dengan memperbanyak praktik dan memperbanyak pelatihan (repetition).

Berdasarkan uraian tersebut, maka rumusan masalah dalam penelitian ini yaitu apakah penerapan model pembelajaran Kooperatif tipe Auditory, Intellectually, Repetition (AIR) berbasis Outdoor Study dapat meningkatkan keterampilan menulis puisi siswa kelas III SD Negeri Soropadan No. 108 Surakarta Tahun Ajaran 2017/2018? Tujuan penelitian ini adalah untuk meningkatkan keterampilan menulis puisi dengan penerapan model pembelajaran Kooperatif tipe Auditory, Intellectually, Repetition (AIR) berbasis Outdoor Study pada siswa kelas III SD Negeri Soropadan No. 108 Surakarta Tahun Ajaran 2017/2018. 


\section{METODE}

Penelitian ini dilaksanakan pada siswa kelas III SD Negeri Soropadan No. 108 Surakarta tahun pelajaran 2017/2018. Waktu penelitian selama kurang lebih delapan bulan yakni dari bulan Desember 2017 sampai dengan Juli 2018. Data yang dikumpulkan dalam penelitian ini berupa hasil wawancara dengan guru dan siswa, hasil observasi, hasil tes pratindakan, serta foto maupun video proses pembelajaran. Sumber data yang digunakan dalam penelitian ini adalah siswa dan guru. Siswa adalah sumber untuk memperoleh data terkait keterampilan menulis puisi, guru adalah sumber untuk memperoleh data tentang hasil wawancara. Guru juga dijadikan sumber untuk memperoleh nilai kinerja guru dalam pembelajaran yang dilaksanakan. Teknik pengumpulan data yang digunakan yaitu observasi, wawancara, dokumentasi dan tes. Validitas data yang digunakan yaitu validitas isi dan triangulasi teknik. Data yang diperoleh dalam penelitian ini dianalisis menggunakan model interaktif Milles dan Huberman.Penelitian ini menggunakan prosedur penelitian yang dilakukan melalui 2 siklus. Setiap siklus terdiri dari empat tahap yaitu perencanaan, tindakan, observasi dan refleksi.

\section{HASIL DAN PEMBAHASAN}

Hasil nilai keterampilan menulis puisi siswa kelas III pada tes pratindakan (pretest) sebelum diterapkannya model pembelajaran Auditory, Intellectually, Repetition (AIR) berbasis Outdoor Study, dapat dibuat tabel distribusi frekuensi. Berikut adalah daftar distribusi frekuensi nilai pretest menulis puisi siswa kelas III SD Negeri Soropadan No. 108 Surakarta yang dapat dilihat pada Tabel 1:

Tabel 1. Distribusi Frekuensi Nilai Pretest Menulis Puisi

\begin{tabular}{|c|c|c|c|c|c|}
\hline \multirow[b]{2}{*}{ Interval Nilai } & \multirow[b]{2}{*}{$\begin{array}{c}\text { Frekuensi } \\
\quad(\mathrm{fi})\end{array}$} & \multirow[b]{2}{*}{$\begin{array}{l}\text { Median } \\
\text { (xi) }\end{array}$} & \multirow[b]{2}{*}{ Fi.xi } & \multicolumn{2}{|c|}{ Persentase } \\
\hline & & & & Relatif & Kumulatif \\
\hline $20-29$ & 10 & 24,5 & 254 & 27,03 & 27,03 \\
\hline $30-39$ & 2 & 34,5 & 69 & 5,41 & 32,44 \\
\hline $40-49$ & 6 & 44,5 & 267 & 16,22 & 48,66 \\
\hline $50-59$ & 3 & 54,5 & 163,5 & 8,1 & 56,76 \\
\hline $60-69$ & 5 & 64,5 & 322,5 & 13,51 & 70,27 \\
\hline $70-79$ & 11 & 74,5 & 819,5 & 29,73 & 100 \\
\hline Jumlah & 37 & & 1886,5 & 100 & \\
\hline Nilai Rata-rata & & & 50,98 & & \\
\hline Ketuntasan Klasikal & & & $29,73 \%$ & & \\
\hline Nilai Tertinggi & & & 75 & & \\
\hline Nilai Terendah & & & 20 & & \\
\hline
\end{tabular}

Berdasarkan data Tabel 1, dapat diketahui bahwa nilai rata-rata pretest keterampilan menulis puisi pada siswa kelas III sebesar 50,98 . Nilai tertinggi adalah 75 dan nilai terendah adalah 20. Siswa yang memperoleh nilai dalam interval 20-29 sebanyak 10 siswa, dengan persentase $27,03 \%$. Siswa yang memperoleh nilai dalam interval 30-39 sebanyak 2 siswa dengan persentase 5,41\%. Siswa dengan interval nilai 40-49 sebanyak 6 siswa dengan persentase 16,22\%. Terdapat 3 siswa memperoleh nilai dalam interval 50-59 dengan persentase 8,1\%. Terdapat 5 siswa yang memperoleh nilai dalam interval 60-69 dengan persentase $13,51 \%$. Siswa yang memperoleh nilai dalam interval 70-79 sebanyak 11 siswa dengan persentase $29,73 \%$. Kemudian diterapkan model pembelajaran Auditory, Intellectually, Repetition (AIR) berbasis Outdoor Study. Penerapan model pembelajaran Auditory, Intellectually, Repetition (AIR) berbasis Outdoor Study menunjukkan adanya peningkatan hasil keterampilan menulis puisi. Hasil keterampilan menulis puisi pada siklus I pertemuan 1 disajikan dalam Tabel 2 sebagai berikut : 
Tabel 2. Distribusi Frekuensi Nilai Menulis Puisi Siklus I Pertemuan 1

\begin{tabular}{|c|c|c|c|c|c|}
\hline \multirow[b]{2}{*}{ Interval Nilai } & \multirow[b]{2}{*}{$\begin{array}{c}\text { Frekuensi } \\
(\mathrm{fi})\end{array}$} & \multirow[b]{2}{*}{$\begin{array}{l}\text { Median } \\
\text { (xi) }\end{array}$} & \multirow[b]{2}{*}{ Fi.xi } & \multicolumn{2}{|c|}{ Persentase } \\
\hline & & & & Relatif & Kumulatif \\
\hline $35-43$ & 3 & 39 & 117 & 8,11 & 8,11 \\
\hline $44-52$ & 6 & 48 & 288 & 16.22 & 24.33 \\
\hline $53-61$ & 6 & 57 & 342 & 16,22 & 40,55 \\
\hline $62-70$ & 10 & 66 & 660 & 27,02 & 67,57 \\
\hline $71-79$ & 9 & 75 & 675 & 24,32 & 91,89 \\
\hline $80-88$ & 3 & 84 & 252 & 8,11 & 100 \\
\hline Jumlah & 37 & & 2334 & 100 & \\
\hline Nilai Rata-rata & \multicolumn{5}{|c|}{63,08} \\
\hline Ketuntasan Klasikal & \multicolumn{5}{|c|}{$35,14 \%$} \\
\hline Nilai Tertinggi & \multicolumn{5}{|c|}{85} \\
\hline Nilai Terendah & \multicolumn{5}{|c|}{35} \\
\hline
\end{tabular}

Nilai rata-rata keterampilan menulis puisi pada siklus I pertemuan 1 adalah 63,08. Ketuntasan klasikal mencapai $35,14 \%$ dan dominasi nilai pada kisaran interval 62-70. Nilai tertinggi adalah 85 dan nilai terendah adalah 35. Hasil penialaian keterampilan menulis puisi pada siklus I pertemuan 2 dilakukan dengan menggunakan pedoman penilaian yang sama dengan pertemuan 1, disajikan pada Tabel 3.

Tabel 3. Distribusi Frekuensi Nilai Menulis Puisi Siklus I Pertemuan 2

\begin{tabular}{|c|c|c|c|c|c|}
\hline \multirow[b]{2}{*}{ Interval Nilai } & \multirow[b]{2}{*}{$\begin{array}{c}\text { Frekuensi } \\
\quad(\mathrm{fi})\end{array}$} & \multirow[b]{2}{*}{$\begin{array}{l}\text { Median } \\
\text { (xi) }\end{array}$} & \multirow[b]{2}{*}{ Fi.xi } & \multicolumn{2}{|c|}{ Persentase } \\
\hline & & & & Relatif & Kumulatif \\
\hline $45-50$ & 2 & 47,5 & 95 & 5,41 & 5,41 \\
\hline $51-56$ & 2 & 53,5 & 107 & 5,41 & 10,82 \\
\hline $57-62$ & 3 & 59,5 & 178,5 & 8,1 & 18,92 \\
\hline $63-68$ & 1 & 65,5 & 65,5 & 2,7 & 21,62 \\
\hline $69-74$ & 18 & 71,5 & 1287 & 48,65 & 70,27 \\
\hline $75-80$ & 11 & 77,5 & 852,5 & 29,73 & 100 \\
\hline Jumlah & 37 & & 2585,5 & 100 & \\
\hline Nilai Rata-rata & & & 69,88 & & \\
\hline Ketuntasan Klasikal & & & $78,38 \%$ & & \\
\hline Nilai Tertinggi & & & 80 & & \\
\hline Nilai Terendah & & & 45 & & \\
\hline
\end{tabular}

Nilai rata-rata keterampilan menulis puisi pada siklus I pertemuan 2 adalah 69,88 . Ketuntasan klasikal mencapai $78,38 \%$ dan dominasi nilai pada kisaran interval 69-74. Nilai tertinggi adalah 80 dan nilai terendah adalah 45. Pada siklus I pertemuan 2 terjadi peningkatan nilai rata-rata dan ketuntasan klasikal dari pertemuan sebelumnya dalam keterampilan menulis puisi. Berdasarkan dua pertemuan yang telah dilakukan, berikut distribusi frekuensi nilai menulis puisi siklus I pada Tabel 4. 
Tabel 4. Distribusi Frekuensi Nilai Menulis Puisi Siklus I

\begin{tabular}{|c|c|c|c|c|c|}
\hline \multirow[b]{2}{*}{ Interval Nilai } & \multirow[b]{2}{*}{$\begin{array}{l}\text { Frekuensi } \\
\text { (fi) }\end{array}$} & \multirow[b]{2}{*}{$\begin{array}{l}\text { Median } \\
(\mathrm{xi})\end{array}$} & \multirow[b]{2}{*}{ Fi.xi } & \multicolumn{2}{|c|}{ Persentase } \\
\hline & & & & Relatif & Kumulatif \\
\hline $45-50$ & 2 & 47,5 & 95 & 5,4 & 5,4 \\
\hline $51-56$ & 7 & 53,5 & 374,5 & 18,92 & 24,32 \\
\hline $57-62$ & 3 & 59,5 & 178,5 & 8,11 & 32,43 \\
\hline $63-68$ & 4 & 65.5 & 262 & 10.81 & 43.24 \\
\hline $69-74$ & 15 & 71,5 & 1072,5 & 40,54 & 83,78 \\
\hline $75-80$ & 6 & 77,5 & 465 & 16,22 & 100 \\
\hline Jumlah & 37 & & 2447,5 & 100 & \\
\hline Nilai Rata-rata & & & 66,15 & & \\
\hline Ketuntasan Klasikal & & & $54,05 \%$ & & \\
\hline Nilai Tertinggi & & & 80 & & \\
\hline Nilai Terendah & & & 45 & & \\
\hline
\end{tabular}

Nilai rata-rata siklus I keterampilan menulis puisi kelas III SD Negeri Soropadan No. 108 Surakarta sebesar 66,15 . Nilai tertinggi adalah 80 dan nilai terendah adalah 45. Ketuntasan klasikal adalah 54,05\%, karena ketuntasan klasikal pada siklus I belum mencapai indikator kinerja penelitian, maka penelitian dilanjutkan pada siklus II.berikut distribusi frekuensi nilai siklus II pertemuan 1 pada Tabel 5.

Tabel 5. Distribusi Frekuensi Nilai Menulis Puisi Siklus II Pertemuan 1

\begin{tabular}{|c|c|c|c|c|c|}
\hline \multirow[b]{2}{*}{ Interval Nilai } & \multirow[b]{2}{*}{$\begin{array}{l}\text { Frekuensi } \\
\text { (fi) }\end{array}$} & \multirow[b]{2}{*}{$\begin{array}{l}\text { Median } \\
(\mathrm{xi})\end{array}$} & \multirow[b]{2}{*}{ Fi.xi } & \multicolumn{2}{|c|}{ Persentase } \\
\hline & & & & Relatif & Kumulatif \\
\hline $50-55$ & 3 & 52,5 & 157,5 & 8,11 & 8,11 \\
\hline $56-61$ & 0 & 58,5 & 0 & 0 & 8,11 \\
\hline $62-67$ & 8 & 64,5 & 516 & 21,62 & 29,73 \\
\hline $68-73$ & 15 & 70,5 & 1057,5 & 40,54 & 70,27 \\
\hline $74-79$ & 4 & 76,5 & 306 & 10,81 & 81,08 \\
\hline $80-85$ & 7 & 82,5 & 577,5 & 18,92 & 100 \\
\hline Jumlah & 37 & & 2614,5 & 100 & \\
\hline Nilai Rata-rata & & & 70,66 & & \\
\hline Ketuntasan Klasikal & & & $70,27 \%$ & & \\
\hline Nilai Tertinggi & & & 85 & & \\
\hline Nilai Terendah & & & 50 & & \\
\hline
\end{tabular}

Nilai rata-rata keterampilan menulis puisi pada siklus II pertemuan 1 adalah 70,66. Ketuntasan klasikal sebesar $70,27 \%$ dengan dominasi nilai pada interval $68-73$. Nilai tertingginya adalah 85 , sedangkan nilai terendahnya 50 . Hasil penialaian keterampilan menulis puisi pada siklus I pertemuan 2 dilakukan dengan menggunakan pedoman penilaian yang sama dengan pertemuan 1, disajikan pada Tabel 6 . 
Tabel 6. Distribusi Frekuensi Nilai Menulis Puisi Siklus II Pertemuan 2

\begin{tabular}{|c|c|c|c|c|c|}
\hline \multirow[b]{2}{*}{ Interval Nilai } & \multirow[b]{2}{*}{$\begin{array}{l}\text { Frekuensi } \\
\text { (fi) }\end{array}$} & \multirow[b]{2}{*}{$\begin{array}{l}\text { Median } \\
(\mathrm{xi})\end{array}$} & \multirow[b]{2}{*}{ Fi.xi } & \multicolumn{2}{|c|}{ Persentase } \\
\hline & & & & Relatif & Kumulatif \\
\hline $55-61$ & 1 & 58 & 58 & 2,7 & 2,7 \\
\hline $62-68$ & 0 & 65 & 0 & 0 & 2,7 \\
\hline $69-75$ & 15 & 72 & 1080 & 40,54 & 43,24 \\
\hline $76-82$ & 18 & 79 & 1422 & 48.65 & 91.89 \\
\hline $83-89$ & 2 & 86 & 172 & 5,41 & 97,3 \\
\hline $90-96$ & 1 & 93 & 93 & 2,7 & 100 \\
\hline Jumlah & 37 & & 2825 & 100 & \\
\hline Nilai Rata-rata & & & 76,35 & & \\
\hline Ketuntasan Klasikal & & & $97,3 \%$ & & \\
\hline Nilai Tertinggi & & & 95 & & \\
\hline Nilai Terendah & & & 55 & & \\
\hline
\end{tabular}

Nilai rata-rata keterampilan menulis puisi pada siklus II pertemuan 2 adalah 76,35. Ketuntasan klasikal mencapai $97,29 \%$ dan dominasi nilai pada kisaran interval 76-82. Nilai tertinggi adalah 95 dan nilai terendah adalah 55. Berdasarkan dua pertemuan yang telah dilakukan, berikut distribusi frekuensi nilai menulis puisi siklus I pada Tabel 7 .

Tabel 7. Distribusi Frekuensi Nilai Menulis Puisi Siklus II

\begin{tabular}{|c|c|c|c|c|c|}
\hline \multirow[b]{2}{*}{ Interval Nilai } & \multirow[b]{2}{*}{$\begin{array}{l}\text { Frekuensi } \\
\text { (fi) }\end{array}$} & \multirow[b]{2}{*}{$\begin{array}{l}\text { Median } \\
\text { (xi) }\end{array}$} & \multirow[b]{2}{*}{ Fi.xi } & \multicolumn{2}{|c|}{ Persentase } \\
\hline & & & & Relatif & Kumulatif \\
\hline $62,5-66,5$ & 4 & 64,5 & 258 & 10,81 & 10,81 \\
\hline $67,5-71,5$ & 8 & 69,5 & 556 & 21,63 & 32,44 \\
\hline $72,5-76,5$ & 15 & 74,5 & 1117,5 & 40,54 & 72,98 \\
\hline $77,5-81,5$ & 8 & 79,5 & 636 & 21,62 & 94,6 \\
\hline $82,5-86,5$ & 1 & 84,5 & 84,5 & 2,7 & 97,3 \\
\hline $87,5-91,5$ & 1 & 89,5 & 89,5 & 2,7 & 100 \\
\hline Jumlah & 37 & & 2741,5 & 100 & \\
\hline Nilai Rata-rata & & & 74,1 & & \\
\hline Ketuntasan Klasikal & & & $89,19 \%$ & & \\
\hline Nilai Tertinggi & & & 87,5 & & \\
\hline Nilai Terendah & & & 62,5 & & \\
\hline
\end{tabular}

Nilai rata-rata siklus I keterampilan menulis puisi kelas III SD Negeri Soropadan No. 108 Surakarta sebesar 74,09 . Nilai tertinggi adalah 87,5 dan nilai terendah adalah 62,5 . Ketuntasan klasikal yang diperoleh sebesar $89,19 \%$. Ketuntasan klasikal telah memenuhi indikator ketercapaian, yaitu $80 \%$.

Perbandingan nilai keterampilan menulis puisi antarsiklus mengalami peningkatan antar siklusnya. Peningkatan terjadi pada kegiatan prasiklus, siklus I, dan siklus II. Berikut disajikan grafik peningkatan tersebut dalam Gambar 1.

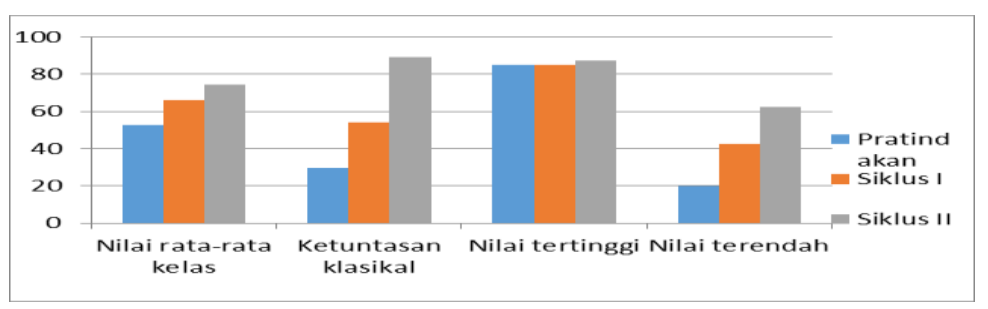




\section{SIMPULAN}

Berdasarkan hasil penelitian tindakan kelas yang telah dilaksanakan dalam dua siklus dapat disimpulkan bahwa penerapan model pembelajaran Auditory, Intellectually, Repetition (AIR) berbasis Outdoor Study dapat meningkatkan keterampilan menulis puisi siswa kelas III SD Negeri Soropadan No. 108 Surakarta tahun ajaran 2017/2018. Implikasi dari penelitian ini meliputi implikasi teoretis dan praktis. Implikasi teoritis yaitu penelitian ini dapat digunakan sebagai referensi penelitian sejenis, khususnya bagi penelitian terkait menulis puisi dan model pembelajaran Auditory, Intellectually, Repetition (AIR) berbasis Outdoor Study. Implikasi praktisnya adalah hasil penelitian dengan penerapan model pembelajaran Auditory, Intellectually, Repetition (AIR) berbasis Outdoor Study memberikan kontribusi terhadap peningkatan kinerja guru, keaktifan siswa, dan keterampilan menulis puisi siswa.

\section{DAFTAR PUSTAKA}

Bento, G. \& Gisela, Dias. (2017). The Importance of Outdoor Play for Young Children's Healthy Development. Porto Biomedical Journal, 2(5):157-160

Dalman. (2016). Keterampilan Menulis. Jakarta: PT Rajagrafindo Persada

Hasnawati. Ikman, \& Sari, Astuti. (2016). Effectiveness Model of Auditory Intellectually Repetition (AIR) to Learning Outcomes Of Math Students. International Journal of Education and Research, 4(5): 249-258

Nurgiyantoro, Burhan. (2016). Penilaian Pembelajaran Bahasa Berbasis Kompetensi. Yogyakarta: BPFE-YOGYAKARTA

Rukayah. (2012). Pedoman Pelaksanaan Pembelajaran Sastra Anak dengan Pendekatan Kooperatif di Sekolah Dasar. Surakarta: UNS Press

Slamet, St. Y., \& Winarni, Retno. (2015). Menulis Puisi: Tematik Integratif Berbasis Pendidikan Budi Pekerti. Surakarta: UNS Press

Winarni, Retno. (2014). Kajian Sastra Anak. Yogyakarta: Graha IImu 